\title{
Satellite Tracking of Eastern Chukchi Sea Beluga Whales into the Arctic Ocean
}

\author{
ROBERT S. SUYDAM, ${ }^{1}$ LLOYD F. LOWRY, ${ }^{2}$ KATHY J. FROST, ${ }^{2}$ GREG M. O'CORRY-CROWE ${ }^{3}$ \\ and DANNY PIKOK, Jr. ${ }^{4}$
}

(Received 25 November 1999; accepted in revised form 10 February 2000)

\begin{abstract}
Beluga whales (Delphinapterus leucas) congregate in nearshore waters of the eastern Chukchi Sea, especially in Kotzebue Sound and Kasegaluk Lagoon, in June and July. Where they travel after they leave this area was unknown before this study. We live-captured five belugas in Kasegaluk Lagoon and attached satellite-linked depth recorders to them. The belugas, caught between 26 June and 1 July 1998, were all males, ranging in length from 398 to $440 \mathrm{~cm}$. A $310 \mathrm{~cm}$ gray beluga accompanied the smallest male. Two tags transmitted for only about two weeks, during which time one animal remained in the vicinity of Icy Cape, $80 \mathrm{~km}$ north of the capture site, and the other traveled to Point Barrow, about $300 \mathrm{~km}$ north. The other three tags operated for $60-104$ days, and those belugas traveled more than $2000 \mathrm{~km}$, reaching $80^{\circ} \mathrm{N}$ and $133^{\circ} \mathrm{W}$, almost $1100 \mathrm{~km}$ north of the Alaska coast. This journey required them to move through $700 \mathrm{~km}$ of more than $90 \%$ ice cover. Two of the whales then moved southward into the Beaufort Sea north and east of Point Barrow. Two whales later moved to an area north of the Mackenzie River delta, where they spent 2-3 weeks before once again heading southwest towards Barrow.
\end{abstract}

Key words: beluga whale, Delphinapterus leucas, Arctic Ocean, Chukchi Sea, movements, satellite telemetry

RÉSUMÉ. En juin et juillet, des bélougas (Delphinapterus leucas) se rassemblent dans les eaux littorales de l'est de la mer des Tchouktches, en particulier dans le détroit de Kotzebue et la lagune de Kasegaluk. Avant la présente étude, on ne savait pas où ils allaient après avoir quitté la région. Dans la lagune de Kasegaluk, on a capturé vivants cinq bélougas qu' on a équipés de sondeurs

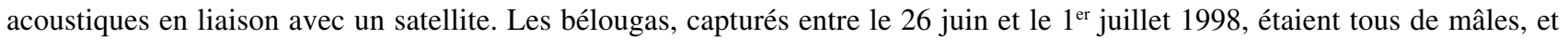
mesuraient de 398 à $440 \mathrm{~cm}$ de long. Un bélouga gris de $310 \mathrm{~cm}$ accompagnait le plus petit mâle. Deux sondes n'ont retransmis que durant deux semaines, au cours desquelles un individu est resté aux environs du cap Icy, à $80 \mathrm{~km}$ au nord du site de capture, tandis que l'autre s'est rendu à la pointe Barrow, à environ $300 \mathrm{~km}$ au nord. Les trois autres sondes ont fonctionné de 60 à 104 jours, période durant laquelle les bélougas ont parcouru plus de $2000 \mathrm{~km}$, atteignant un point situé à $80^{\circ}$ de lat. N. et $133^{\circ}$ de long. O., à environ $1100 \mathrm{~km}$ au nord de la côte alaskienne. Ce voyage exigeait d'eux qu' ils franchissent $700 \mathrm{~km} \mathrm{~d}$ 'eau couverte de glace à plus de 90 p. cent. Deux des baleines ont ensuite viré vers le sud pour pénétrer dans la mer de Beaufort au nord et à l'est de la pointe Barrow. Deux baleines se sont ensuite rendues dans une zone située au nord du delta du Mackenzie, où elles ont passé de 2 à 3 semaines avant de mettre à nouveau le cap sur le sud-ouest, en direction de Barrow.

Mots clés: bélouga, baleine blanche, Delphinapterus leucas, océan Arctique, mer des Tchouktches, déplacements, télémesure par satellite

Traduit pour la revue Arctic par Nésida Loyer.

\section{INTRODUCTION}

Beluga whales (Delphinapterus leucas) occur in coastal and offshore waters of western and northern Alaska (Hazard, 1988; Seaman et al., 1988; Frost and Lowry, 1990). During the summer months, they concentrate predictably in certain coastal locations to feed, calve, and molt. This predictable distribution was used to identify three provisional management stocks in western Alaska (Seaman et al., 1988; Frost and Lowry, 1990). Studies of mitochondrial DNA have confirmed the existence of three stocks that occur during summer in western Alaska and a fourth in northwestern Canada. These are the belugas of Bristol Bay, the eastern Bering Sea, the eastern Chukchi Sea, and the eastern Beaufort Sea (O'Corry-Crowe et al., 1997).

Beluga whales have been seen all along the coast of the eastern Chukchi Sea during summer, but they are most common in Kotzebue Sound and near Kasegaluk Lagoon (Frost and Lowry, 1990). Belugas apparently have been using the Kasegaluk Lagoon region during summer for many years. Warren Neakok described hunting them there in about 1930 (Neakok et al., 1985). In recent years, the occurrence of belugas at Kasegaluk Lagoon has been quite predictable: they usually arrive in late June or early July

\footnotetext{
${ }^{1}$ North Slope Borough Department of Wildlife Management, Box 69, Barrow, Alaska 99723, U.S.A.; rsuydam@co.north-slope.ak.us

${ }^{2}$ Alaska Department of Fish and Game, 1300 College Rd., Fairbanks, Alaska 99701, U.S.A.

${ }^{3}$ Southwest Fisheries Science Center, National Marine Fisheries Service, P.O. Box 271, La Jolla, California 92038, U.S.A.

${ }^{4}$ P.O. Box 59117, Point Lay, Alaska 99759, U.S.A.

(C) The Arctic Institute of North America
} 
(Frost and Lowry, 1990; Huntington et al., 1999), and the latest sightings of belugas near the lagoon usually occur in mid to late July (Frost and Lowry, 1990; Huntington et al., 1999). The distribution and movements of the whales after that time were completely unknown before this study. We suspected that they moved north and spent the summer along the edge of the pack ice in the Chukchi Sea or western Beaufort Sea.

Our understanding of the biology of beluga whales from the eastern Chukchi Sea stock is very limited. Aerial surveys have provided some information on distribution and movements during June-July (Seaman et al., 1988; Frost and Lowry, 1990); examination of biological samples from belugas taken in subsistence hunts has provided insights into growth and reproduction (Burns and Seaman, 1988); and genetic analyses have provided a better understanding of stock relationships (O'Corry-Crowe et al., 1997). Recent advances in technology, such as satellitelinked tags, have provided opportunities to study belugas and other marine mammals in new ways.

Frost et al. (1985) were the first to use telemetry to study the movements and behavior of belugas. They attached VHF radios to the dorsal ridges of two belugas in Bristol Bay, Alaska, and tracked their movements for about two weeks. More recently, similar techniques have been used to attach satellite-linked transmitters to beluga whales in several areas of the Canadian Arctic (Martin et al., 1993; Smith and Martin, 1994; Richard et al., 1997, 1998a,b). Satellite-linked transmitters have allowed belugas to be tracked over greater areas and for longer periods of time.

Beluga whales from the eastern Chukchi Sea stock are an important subsistence resource for residents of the village of Point Lay, adjacent to Kasegaluk Lagoon, and other villages in northwest Alaska. Each year, hunters from Point Lay drive belugas into the lagoon to a traditional hunting location. This technique provides opportunities to live-capture belugas that remain in the lagoon after the hunt.

In this paper, we present results from a project initiated by the Alaska Beluga Whale Committee to live-capture and attach satellite-linked depth recorders (SDRs) to belugas. In 1998, we worked cooperatively with people from the village of Point Lay to capture and tag five whales in Kasegaluk Lagoon. Our objectives were to track movements and document diving behavior of belugas after their departure from the area of Kasegaluk Lagoon. In this paper, we present only movement data. Dive data will be presented in the future when our sample size is larger.

\section{METHODS}

\section{Capture and Tagging of Whales}

In 1996 and 1997, we were not successful in our attempts to capture belugas in or near Kasegaluk Lagoon. In 1996, no belugas remained in the lagoon after the drive hunt, and in 1997 few belugas were seen near Point Lay. On 26 June 1998, the hunters of Point Lay drove approximately 80 belugas into Kasegaluk Lagoon. Of these, 48 were killed and approximately 30 remained alive in the lagoon. Between 26 June and 1 July 1998, we captured five of these remaining belugas (all males) in two different ways. The first animal was captured during the drive hunt as it attempted to escape; a hoop net as described by Martin and Smith (1992) was used. The other four were captured with a set net, $200 \mathrm{~m}$ long, $4 \mathrm{~m}$ deep, and with $37.5 \mathrm{~cm}$ stretched mesh. The net was set across the channel of the lagoon. Individual whales were driven into the net, where they became entangled. Each whale was further secured with a hoop net over its head and flippers. A padded rope was secured around the caudal peduncle, and the beluga was towed to shore. The whales were held in water shallow enough to expose their dorsa. They were released immediately after the transmitters were attached.

The transmitters, manufactured by Wildlife Computers, were attached to a nylon saddle. Each tag with saddle weighed approximately $750 \mathrm{~g}$ and measured $14.8 \times 10.0 \times$ $3.8 \mathrm{~cm}$. The tags, powered by $4 \mathrm{C}$-cell lithium batteries, each had an output of 0.5 watts. They collected data continuously, but a conductivity switch allowed transmissions only when the tag was out of the water. The transmitters were attached with four nylon or dacron pins, each about $0.33 \mathrm{~m}$ long. These pins were inserted through the skin and blubber of the dorsal ridge. They fit through precut holes in the saddle of each transmitter, and nylon or dacron washers and nuts held the saddle and transmitter to the back of each animal. This attachment technique reportedly has little long-term impact on beluga whales (Orr et al., 1998). However, the pins migrate out of the dorsal ridge, which leads to release of the transmitter and loss of signals. Using different materials for the pins may influence time of tag retention, although we observed no association between tag longevity and pin type.

The whale that was captured and tagged during the drive hunt was guided out of Kasegaluk Lagoon shortly after tagging. The other belugas remained in the channels of the lagoon for 2-5 days after they were tagged. We attempted to drive them out on 2 July, but they remained in the deeper channels and would not cross over shallow areas. On 3 July, the water level in the lagoon rose, and the belugas left of their own accord.

\section{Satellite Tag Data Analysis}

Data from the satellite-tagged belugas were obtained from Service ARGOS (see ARGOS, 1988 and Fancy et al., 1988 for a detailed description of the ARGOS data collection and location system). Data included a location for the SDR if sufficient signals were received during a satellite pass, or dive and battery strength data if only one uplink occurred. Service ARGOS assigns a location quality code to each location record that it provides. In our analysis we used all location qualities except class "Z," 
TABLE 1. Performance of satellite-linked depth recorders attached to male beluga whales at Kasegaluk Lagoon, Alaska, June-July 1998.

\begin{tabular}{|c|c|c|c|c|c|c|}
\hline $\mathrm{SDR}^{1}$ & $\begin{array}{l}\text { Whale Length } \\
\qquad(\mathrm{cm})\end{array}$ & $\begin{array}{c}\text { Date } \\
\text { Attached }\end{array}$ & $\begin{array}{l}\text { Date of Last } \\
\text { Location }\end{array}$ & $\begin{array}{l}\text { Total Days } \\
\text { Operational }\end{array}$ & $\begin{array}{c}\text { No. Days } \\
\text { w/ Locations }\end{array}$ & $\begin{array}{l}\text { Total No. } \\
\text { Locations }\end{array}$ \\
\hline 11035 & 440 & June 26 & July 8 & 13 & 12 & 312 \\
\hline 11036 & 398 & June 29 & October 10 & 104 & 91 & 1267 \\
\hline 2282 & 414 & July 1 & August 29 & 60 & 56 & 801 \\
\hline 2284 & 432 & June 28 & July 12 & 15 & 11 & 172 \\
\hline 2285 & 415 & June 29 & September 28 & 92 & 63 & 745 \\
\hline
\end{tabular}

${ }^{1} \mathrm{SDR}=$ Satellite-linked depth recorder number.

which consists of those records that do not pass ARGOS plausibility tests. ARGOS predicts that locations of quality code 3 are within $150 \mathrm{~m}$ of the actual location; those with code 2 are within $350 \mathrm{~m}$; code 1 locations are within $1 \mathrm{~km}$; and code 0 locations are more than $1 \mathrm{~km}$ away (ARGOS, 1988), although there is evidence that the locations are not this accurate (Burns and Castellini, 1998; Goulet et al., 1999).

We screened location records using a computer program that calculated the time, distance, and speed between sequential pairs of locations. The program identified pairs of records that were improbable or that indicated apparent speeds greater than $20 \mathrm{~km} /$ hour over periods longer than 10 minutes. We inspected the identified records visually and deleted the ones that appeared erroneous. The location records used in this paper include only those that remained after the screening process.

For analysis and presentation, dates and times reported by Service ARGOS were converted from Greenwich Mean Time to true local time by subtracting 11 hours. A computer program calculated the average daily position for each whale on the basis of all records obtained during a 24-hour period, local time.

Data on sea ice coverage were obtained from the $\mathrm{Na}$ tional Oceanic and Atmospheric Administration's National Ice Center. Average daily positions for belugas and sea ice coverage maps were displayed and analyzed with the geographic information systems ArcInfo and ArcView.

\section{RESULTS}

The five male belugas ranged in length from 398 to $440 \mathrm{~cm}$. A $310 \mathrm{~cm}$ gray-colored male accompanied the $398 \mathrm{~cm}$ male in a calf-like manner. We refer to the whales by their SDR identification numbers (Table 1).

SDRs provided location information over periods ranging from 13 to 104 days. Two of the tags failed after approximately 2 weeks, while the other three operated for 2 to 3.5 months. Individual whales were located on 68 $93 \%$ of the days they were tracked. In most cases, location data were received for each whale every day. The main exception was beluga 2285 , for which no locations were received (for unknown reasons) from 30 August through 18 September. The average number of locations received per SDR per day ranged from 8.1 to 24.0.
From the time they were tagged through 12 July, the belugas stayed in the northeastern Chukchi Sea between Point Lay and Point Barrow (Fig. 1). Beluga 11035 moved out of Kasegaluk Lagoon shortly after it was tagged and remained in open water off the northern part of Kasegaluk Lagoon until 8 July (when signals stopped). The other four tagged belugas left the lagoon on 3-4 July and moved first northward, then northeastward, to the vicinity of Point Barrow. Three of them $(11036,2282,2285)$ then moved westward back toward Icy Cape during 8-10 July. No signals were received from the fourth animal (2284) during those days. The maximum distances between average daily locations of the four whales were $11-100 \mathrm{~km}$. On 12 July, the four belugas with transmitting SDRs were all north of Point Barrow, and their average locations for that day were within $17 \mathrm{~km}$ of one another. All locations for these four whales during 5-12 July were in ice cover of greater than $90 \%$.

From 12 to 31 July, the three belugas with functioning tags moved steadily northward (Fig. 2). They traveled as a group: the greatest distance between average daily locations during this period was $45 \mathrm{~km}$. The whales moved through ice of greater than $90 \%$ coverage to a point north of $80^{\circ} \mathrm{N}$, about $1100 \mathrm{~km}$ north of the Alaska coast. They traveled $1120 \mathrm{~km}$ in 19 days, averaging $59 \mathrm{~km}$ per day. After they reached their northernmost location, two of the animals (11036 and 2282) immediately headed south, again traveling together through ice of greater than $90 \%$ coverage. They reached open water on 8 August, having moved $620 \mathrm{~km}$ in 8 days $(78 \mathrm{~km} / \mathrm{day})$. The other whale (2285) remained in the north until 5 August, after which time it moved south along a different route. It reached open water on 16 August, having covered $630 \mathrm{~km}$ in 8 days (79 km/day).

Belugas 2282 and 11036 continued traveling southward together in open water until 10 August, when they separated. Beluga 11036 then moved to an area of loose ice east of Point Barrow, while 2282 turned back northward into heavy pack ice (Fig. 3). When beluga 2285 reached open water, it swam westward approximately $500 \mathrm{~km}$ to the edge of loose pack ice, which it then followed back toward the east. During August-September, the three belugas moved independently, covering a large part of the Beaufort Sea and adjacent Arctic Basin. All three used an area just north of the shelf break between Point Barrow and Prudhoe Bay and a region of pack ice 400-600 km north 


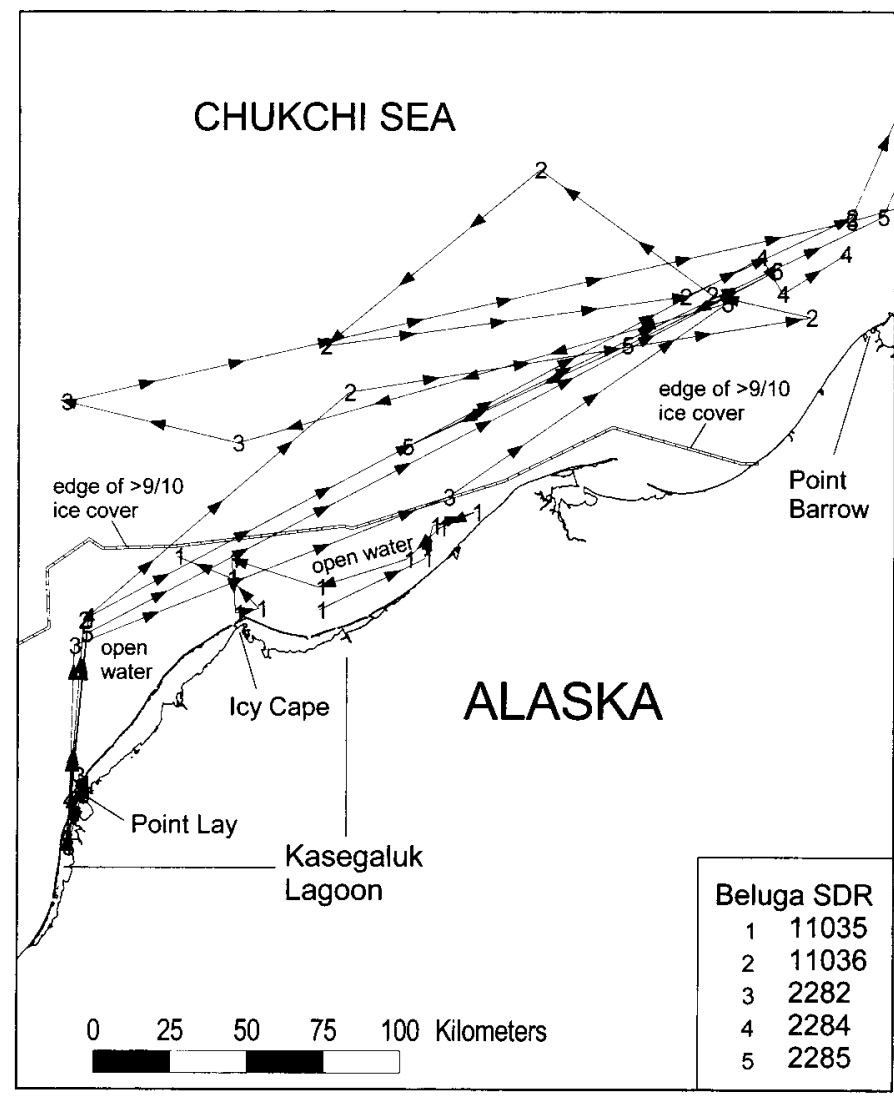

FIG. 1. Movements during 26 June-12 July 1998 of beluga whales satellitetagged near Point Lay, Alaska.

of the Mackenzie River delta. The maximum distance apart for pairs of tagged whales on individual days was $620-717 \mathrm{~km}$ (Fig. 4). The three belugas were separated to the greatest extent on 22 August, when the closest pair of locations was more than $400 \mathrm{~km}$ apart. On 29 August, they were all near the shelf break northeast of Barrow, within $55-120 \mathrm{~km}$ of one another. On 22 September, the two whales with functioning tags (11036 and 2285) were only $7 \mathrm{~km}$ apart at a location $600 \mathrm{~km}$ north of the Mackenzie delta. Six days later, those whales were $294 \mathrm{~km}$ apart, after one had moved to the southeast and the other to the southwest. The last signals were received from beluga 11036 on 10 October, when it was approximately $400 \mathrm{~km}$ northeast of Point Barrow.

Location data and ice maps indicate that two of the tagged belugas spent 34 days $(60.7 \%$ of days with locations) and one spent 42 days ( $46.2 \%$ of days with locations) in ice of greater than $90 \%$ coverage. When moving steadily, they covered average distances of $59-79 \mathrm{~km} /$ day $(2.5-3.3 \mathrm{~km} / \mathrm{h})$ through the ice.

\section{DISCUSSION}

Initial movements of the tagged belugas were as expected. All five whales moved northeastward from the capture location near Point Lay. One remained relatively

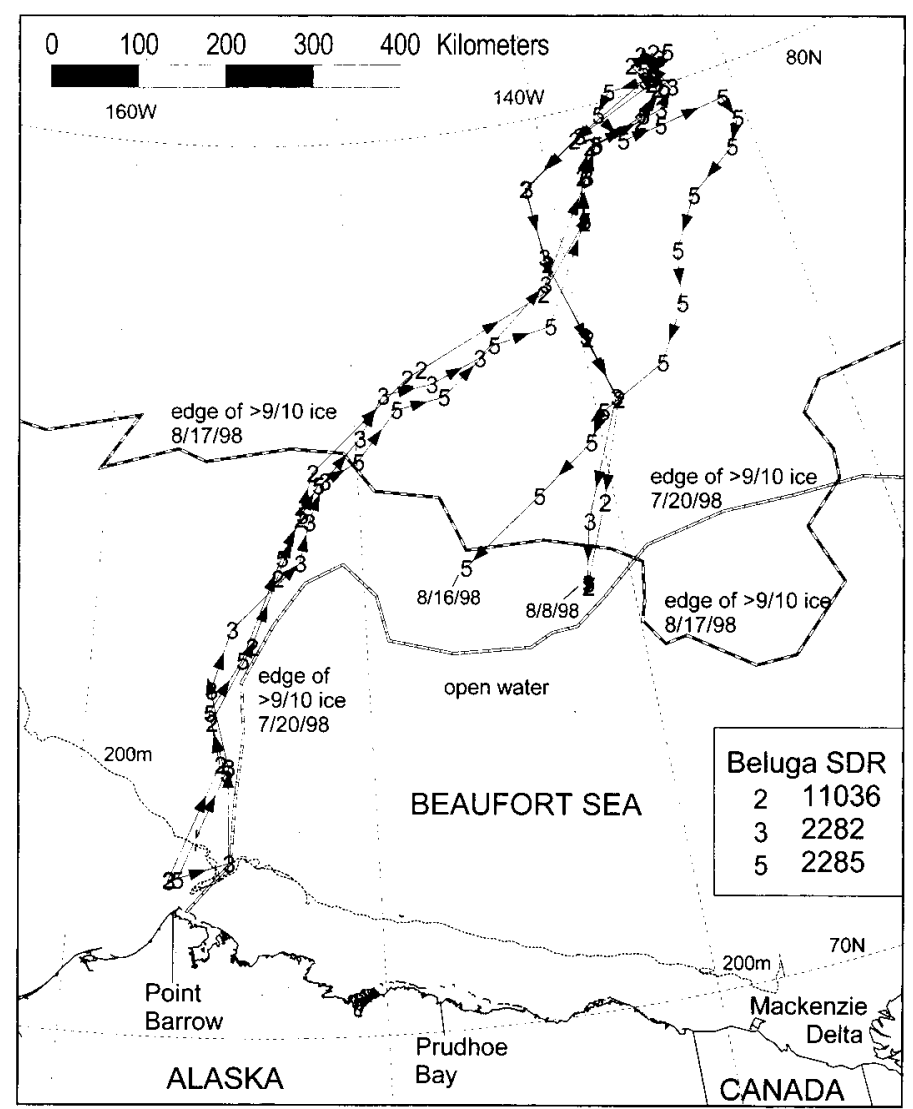

FIG. 2. Movements during 12 July-19 August 1998 of beluga whales satellitetagged near Point Lay, Alaska.

near shore in open water near Icy Cape. The telemetry locations from this whale, animal 11035, allowed an aerial survey crew to locate a large group of belugas on 6 July, when 1172 whales were counted near Icy Cape and in the ice just offshore (Lowry et al., 1999). (Such an aggregation is normal for that time of year. Frost et al. (1993) flew 24 aerial surveys in the Kasegaluk Lagoon region during 3-14 July 1990 and 4-16 July 1991 and saw belugas on every flight. Their highest single-day count of 1212 whales occurred on 6 July 1991.) The other four tagged belugas moved into heavy ice cover about $180 \mathrm{~km}$ north of Icy Cape and were there at the same time that the large group was counted near Icy Cape. We do not know how many additional whales may have been associated with these four tagged individuals.

The movements of tagged belugas, after the initial northeastward movement, were unexpected. They traveled far north into the Arctic Ocean and deep into the pack ice. The reasons for the observed movements are unknown. Since two of the belugas immediately headed south after reaching their northernmost point, it seems reasonable to conclude that the circumstances there were not particularly suitable. However, one beluga did remain at $80^{\circ} \mathrm{N}$ for almost a week. The direct and coordinated movements of the three animals were purposeful, possibly indicating prior knowledge of a resource. One such resource, arctic cod (Boreogadus saida), can occur in dense patches and is 


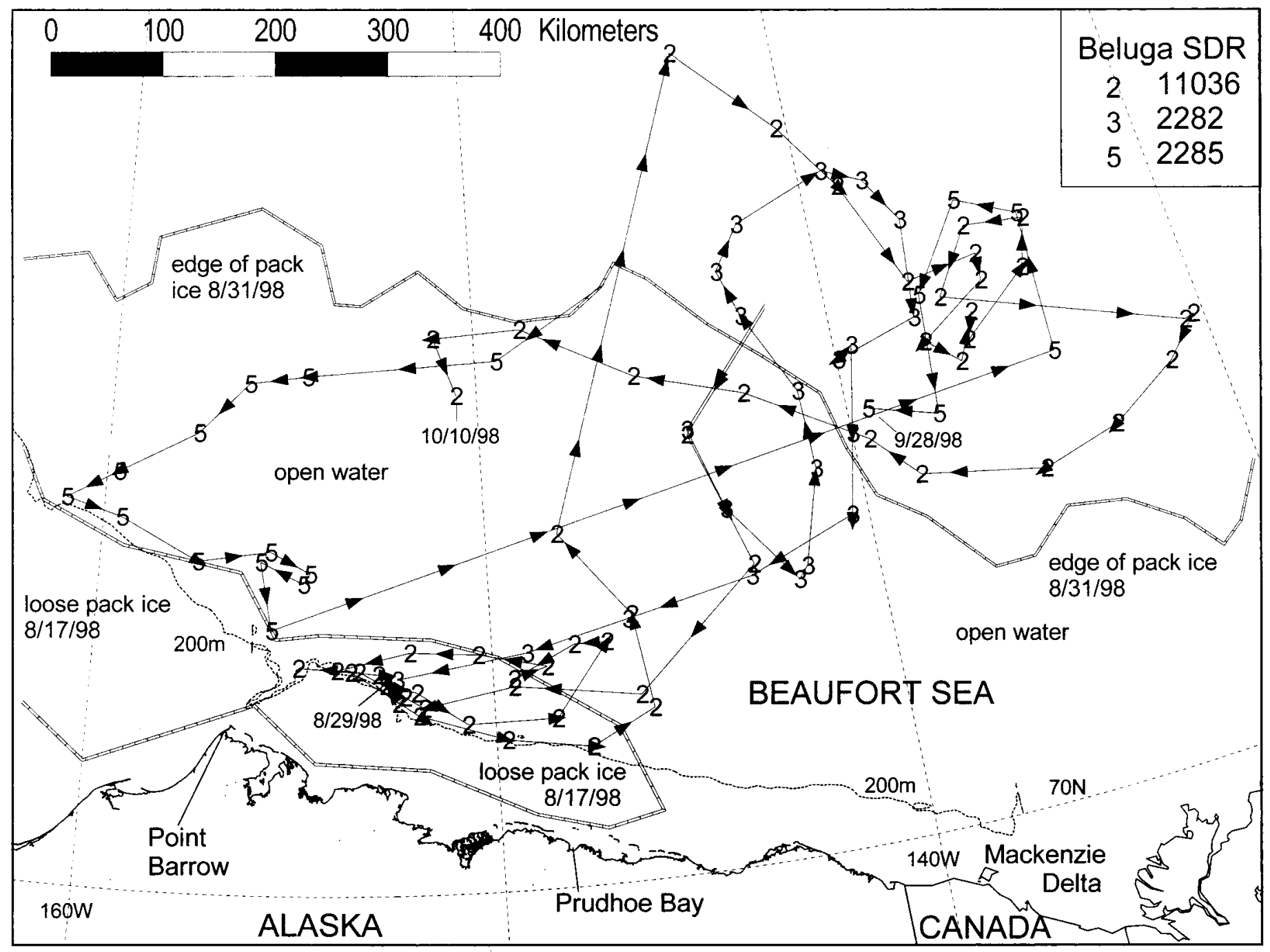

FIG. 3. Movements during 19 August-10 October 1998 of beluga whales satellite-tagged near Point Lay, Alaska.

an important food of marine mammals in the Arctic (Finley et al., 1990; Welch et al., 1993). However, there are no data on distribution or concentrations of arctic cod or other beluga food items so far north.

During summer, the tagged belugas moved to deep offshore waters $(\sim 3000 \mathrm{~m})$ with heavy ice cover (more than $90 \%$ ). Their use of deep, offshore habitat was different from that previously reported for belugas in summer. Tagged belugas from other areas have tended to remain in relatively nearshore waters, although often in deep water (Smith and Martin, 1994; Richard et al., 1997, 1998a,b). Belugas tagged in the eastern Canadian Arctic remained within the Canadian Arctic Archipelago and mostly within or near estuaries (Smith and Martin, 1994). Female belugas tagged in the Mackenzie River delta also remained mostly near shore and in relatively shallow water, while males spent little time in the delta and traveled north, presumably to feed in nearshore water with heavy ice cover (Richard et al., 1997, 1998b). Smith and Martin (1994) thought that ice melt in summer dictated when and where belugas could move within Peel Sound. It is obvious that ice did not restrict the movements of the tagged belugas we tracked in the Arctic Ocean, but the ice conditions there may be less hazardous for belugas to navigate than those in the geographically complex Canadian Arctic Archipelago.

The belugas we tagged moved far to the north in a short time and to a place that we did not anticipate. It is unknown whether those movements were typical of eastern Chukchi Sea belugas. Before this study, there was no information on where eastern Chukchi Sea belugas spent the summer after leaving the area near Kasegaluk Lagoon. It is feasible that the entire stock spends the summer in the pack ice of the Arctic Ocean. Regardless of why belugas moved so far north, the tagged whales showed that they are capable of moving great distances in almost complete ice cover.

The three whales that traveled farthest north provided insight into association or grouping patterns in this species. They were caught from the same herd, traveled together most of the time when moving through heavy ice, and moved more independently after they reached areas of open water and looser ice. Locations paired by date show that the whales were frequently separated by more than $400 \mathrm{~km}$. Nonetheless, they either deliberately managed to 

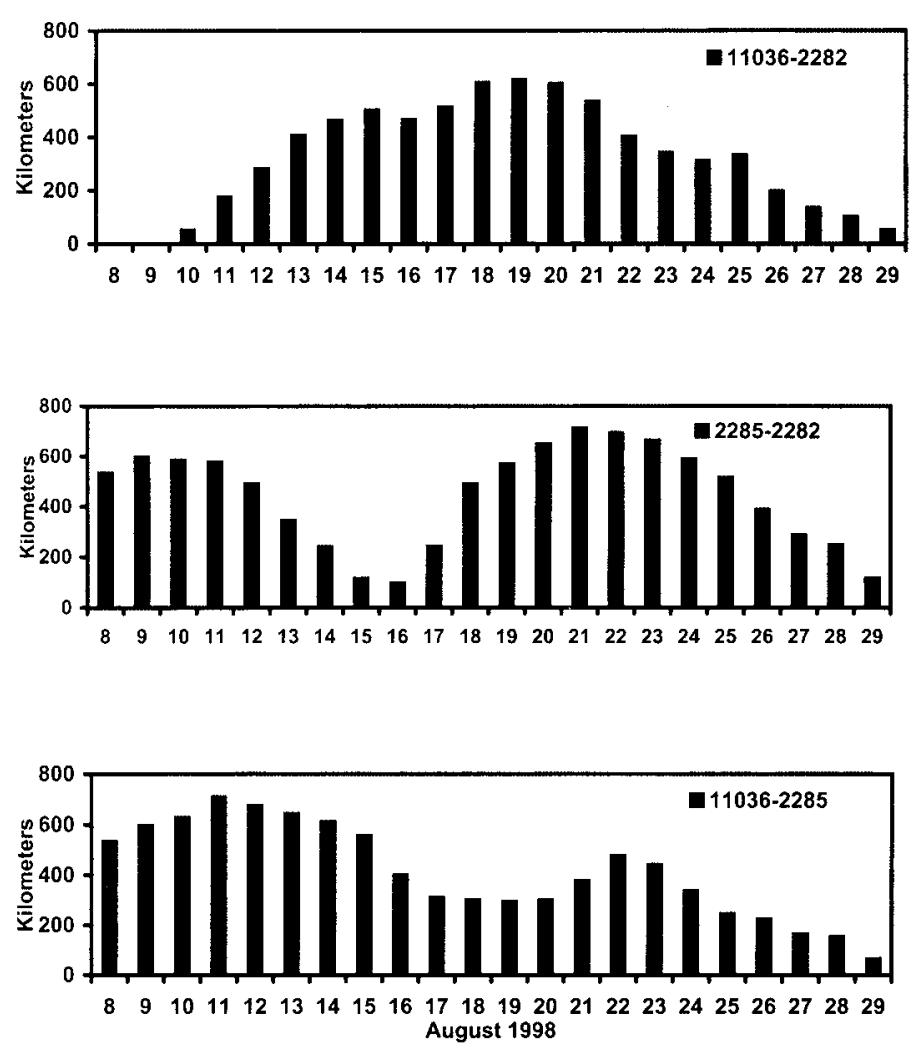

FIG. 4. Daily distance (in $\mathrm{km}$ ) between belugas \#11036, \#2282, and \#2285 during 8-29 August 1998.

find one another again or happened to converge on the same area. Two whales that were more than $700 \mathrm{~km}$ apart on 13 August were only $7 \mathrm{~km}$ apart on 23 September.

During fall migration, tagged belugas in eastern Canada typically used deeper waters between islands (Smith and Martin, 1994). In the Beaufort Sea, they mostly moved along the shelf break, although a small number migrated through the heavy ice near $75^{\circ} \mathrm{N}$, far north of the shelf break (Richard et al., 1997, 1998b). The westward fall migration of the eastern Beaufort Sea stock occurs in mid to late September and October (Treacy, 1994; Richard et al., 1997, 1998b). Assuming that the eastern Beaufort Sea stock migrated at the same time in 1998 as in previous years, it is likely that the eastern stock and our tagged belugas from the eastern Chukchi Sea appeared in similar places and at similar times during the fall. The significance of the apparent overlap or mingling of these two stocks in early fall is uncertain.

Estimated swimming speeds $(2.5-3.3 \mathrm{~km} / \mathrm{h})$, derived from distances covered by our belugas, are similar to those calculated in other studies. Smith and Martin (1994) estimated swimming speeds of $1.1-1.85 \mathrm{~km} / \mathrm{h}$ during the entire period of their study, which included considerable time spent by the whales in estuaries. They calculated speeds of $1.6-5.99 \mathrm{~km} / \mathrm{h}$ during the fall migration. Richard et al. (1998b) observed belugas moving mostly at 1$10 \mathrm{~km} / \mathrm{h}$ during the fall, but they also calculated several speeds of more than $20 \mathrm{~km} / \mathrm{h}$. Undoubtedly, the speed at which belugas travel depends upon the season and activity: they would be expected to travel faster while on migration than while feeding or molting.

Our tag longevity, 13 to 104 days, was similar to that experienced in other studies of beluga whales. Smith and Martin (1994) received signals for periods of less than 1 to 75 days; Richard et al. (1997), for 7 to 91 days; Richard et al. (1998a), for 37 to 60 days; and Richard et al. (1998b), for 56 to 120 days. The longevity of the tags appears to be limited by the attachment technique. The nylon pins holding the tag onto the beluga eventually pull out of the blubber and skin of the dorsal ridge, and the tag falls off (Orr et al., 1998). To obtain greater tag longevity, we need a different attachment technique, a modified transmitter size or shape, or both.

Our results show that beluga whales are not necessarily limited by heavy ice cover and that they are capable of moving great distances in a relatively short time. Mixed groups of whales may remain in cohesive units for weeks or months or, alternatively, may separate and move as much as $700 \mathrm{~km}$ apart, only to converge at a later time. Furthermore, during the summer belugas from the eastern Chukchi Sea stock use offshore areas with heavy ice cover, as well as loose ice cover, open water, and nearshore waters. Interpretation of our results is limited by the very small sample size. Further tagging studies to increase sample size will help elucidate both the movement patterns of beluga whales of the eastern Chukchi Sea and their use of habitat.

\section{ACKNOWLEDGEMENTS}

Many people provided assistance in the capturing and tagging of beluga whales near Point Lay. Hunters of Point Lay were very supportive of this project, especially Warren and Dorcus Neakok, Gordon Upicksoun, Thomas Nukapigak, Amos Agnasagga, Julius Rexford, and Bill Tracey, Sr. Many thanks to Jack Orr, Alvin Ashby, Vince Dollarhide, Leo Ferreira III, Rod Hobbs, Thomas Nukapigak, Tracy Romano, Michelle Sparck, Suzann Speckman, Danny Susook, and Jim Tazruk for assisting with capturing and tagging. Logistical support was provided by Bill Tracey Sr., Marie Tracey, Jack Talyor, Jerry Edwards, and Danny Susook in Point Lay and by Dave Ramey and Ben Achootchook in Barrow. Additional support was received from Douglas DeMaster, Thomas F. Albert, Charles D.N. Brower, Dolores Vinas, Liza Delarosa, April Brower, and John Bengston. Gay Sheffield helped with analysis and presentation of SDR location data. Janice Waite assisted with permit requirements. Helpful comments on earlier drafts of this manuscript were received from John Burns, Randy Reeves, Glenn VanBlaricom, and one anonymous reviewer. This project was funded mostly by a grant from the National Oceanic and Atmospheric Administration to the Alaska Beluga Whale Committee. Additional support was provided by the North Slope Borough Department of Wildlife Management, the Alaska Department of Fish and Game, the National Marine Mammal Laboratory of the National Marine Fisheries Service, and the North Slope Borough Grants Division and School District. 


\section{REFERENCES}

ARGOS. 1988. Users' manual, Version 1. Toulouse, France: CLS ARGOS

BURNS, J.M., and CASTELLINI, M.A. 1998. Dive data from satellite tags and time-depth recorders: A comparison in Weddell Seal pups. Marine Mammal Science 14:750-764.

BURNS, J.J., and SEAMAN, G.A. 1988. Investigations of belukha whales in coastal waters of western and northern Alaska. II. Biology and ecology. U.S. Department of Commerce, NOAA, OCSEAP Final Report 56:221-357. Available from NOAAOMA-OAD, Alaska Office, $701 \mathrm{C}$ Street, Anchorage, Alaska 99513.

FANCY, S.C., PANK, L.F., DOUGLAS, D.C., CURBY, C.H., GARNER, G.W., AMSTRUP, S.C., and REGELIN, W.L. 1988. Satellite telemetry: A new tool for wildlife research and management. U.S. Fish and Wildlife Service Resource Publication No. 172.54 p. Available from U.S. Fish and Wildlife Service, 1011 Tudor Road, Anchorage, Alaska 99503.

FINLEY, K.J., BRADSTREET, M.S.W., and MILLER, G.W. 1990. Summer feeding ecology of harp seals (Phoca groenlandicus) in relation to arctic cod (Boreogadus saida) in the Canadian High Arctic. Polar Biology 10:609-618.

FROST, K.J., and LOWRY, L.F. 1990. Distribution, abundance, and movements of beluga whales, Delphinapterus leucas, in coastal waters of western Alaska. In: Smith, T.G., St. Aubin, D.J., and Geraci, J.R., eds. Advances in research on the beluga whale, Delphinapterus leucas. Canadian Bulletin of Fisheries and Aquatic Sciences 224. 39-57.

FROST, K.J., LOWRY, L.F., and NELSON, R.R. 1985. Radiotagging studies of beluga whales (Delphinapterus leucas) in Bristol Bay, Alaska. Marine Mammal Science 1:191-202.

FROST, K.J., LOWRY, L.F., and CARROLL, G. 1993. Beluga whale and spotted seal use of a coastal lagoon system in the northeastern Chukchi Sea. Arctic 46(1):8-16.

GOULET, A.-M., HAMMILL, M.O., and BARRETTE, C. 1999. Quality of satellite telemetry locations of gray seals (Halichoerus grypus). Marine Mammal Science 15:589-594.

HAZARD, K. 1988. Beluga whale, Delphinapterus leucas. In: Lentfer, J.W., ed. Selected marine mammals of Alaska. Washington, D.C.: Marine Mammal Commission. 195-235.

HUNTINGTON, H.P., and THE COMMUNITIES OF BUCKLAND, ELIM, KOYUK, POINT LAY, AND SHAKTOOLIK. 1999. Traditional knowledge of the ecology of beluga whales (Delphinapterus leucas) in the eastern Chukchi and northern Bering Seas, Alaska. Arctic 52(1):49-61.

LOWRY, L.F., DeMASTER, D.P., FROST, K.J., and PERRYMAN, W. 1999. Alaska Beluga Whale Committee surveys of beluga whales in the eastern Chukchi Sea, 1996-1998. Alaska Beluga Whale Committee Report 99-1. 13 p. Available from Alaska Department of Fish and Game, 1300 College Road, Fairbanks, Alaska 99701.

MARTIN, A.R., and SMITH, T.G. 1992. Deep diving in wild, freeranging beluga whales, Delphinapterus leucas. Canadian Journal of Fisheries and Aquatic Sciences 49:462-466.
MARTIN, A.R., SMITH, T.G., and COX, O.P. 1993. Studying the behaviour and movements of High Arctic belugas with satellite telemetry. Symposia of the Zoological Society of London 66: 195-210.

NEAKOK, W., NEAKOK, D., BODFISH, W., LIBBEY, D., HALL, E.S. Jr., and the POINT LAY ELDERS. 1985. To keep the past alive: The Point Lay cultural resource site survey. Barrow, Alaska: North Slope Borough. 111 p. Available from North Slope Borough, Box 69, Barrow, Alaska 99723.

O'CORRY-CROWE, G.M., SUYDAM, R.S., ROSENBERG, A., FROST, K.J., and DIZON, A.E. 1997. Phylogeography, population structure and dispersal patterns of the beluga whale Delphinapterus leucas in the western Nearctic revealed by mitochondrial DNA. Molecular Ecology 6:955-970.

ORR, J., ST. AUBIN, D.J., RICHARD, P.R., and HEIDEJØRGENSEN, M.P. 1998. Recapture of belugas, Delphinapterus leucas, tagged in the Canadian Arctic. Marine Mammal Science 14:829-834.

RICHARD, P.R., MARTIN, A.R., and ORR, J.R. 1997. Study of summer and fall movements and dive behavior of Beaufort Sea belugas, using satellite telemetry: 1992-1995. Environmental Studies Research Funds Report No. 134. 26 p. Available from Fisheries and Oceans, Resource Management Division, Freshwater Institute, 501 University Crescent, Winnipeg, Manitoba R3T 2N6.

RICHARD, P.R., HEIDE-JÆRGENSEN, M.P., and ST. AUBIN. D. 1998a. Fall movements of belugas (Delphinapterus leucas) with satellite-linked transmitters in Lancaster Sound, Jones Sound, and northern Baffin Bay. Arctic 51(1):5-16.

RICHARD, P.R., MARTIN, A.R., and ORR, J.R. 1998b. Study of late summer and fall movements and dive behavior of Beaufort Sea belugas, using satellite telemetry: 1997. Final Report Minerals Management Service OCS Study 98-0016. 25 p. Available from Fisheries and Oceans, Resource Management Division, Freshwater Institute, 501 University Crescent, Winnipeg, Manitoba R3T 2N6.

SEAMAN, G.A., FROST, K.J., and LOWRY, L.F. 1988. Investigations of belukha whales in coastal waters of western and northern Alaska. Part I. Distribution and abundance. U.S. Department of Commerce, NOAA, OCSEAP Final Report 56:153-220. Available from NOAA-OMA-OAD, Alaska Office, 701 C Street, Anchorage, Alaska 99513.

SMITH, T.G., and MARTIN, A.R. 1994. Distribution and movements of belugas, Delphinapterus leucas, in the Canadian High Arctic. Canadian Journal of Fisheries and Aquatic Sciences 51:1653-1663.

TREACY, S.D. 1994. Aerial surveys for endangered whales in the Beaufort Sea, fall 1993. OCS Study, MMS 94-0032. U.S. Department of the Interior, Minerals Management Service, Alaska OCS Region. Available from Minerals Management Service, 949 E. 36th Ave, Room 110, Anchorage, Alaska 99508. WELCH, H.E., CRAWFORD, R.E., and HOP, H. 1993. Occurrence of arctic cod (Boreogadus saida) schools and their vulnerability to predation in the Canadian High Arctic. Arctic 46(4):331 - 339. 